\title{
Breast tumour stroma is a prognostic indicator and target for therapy
}

Anthony Howell*, Goran Landberg and Jonas Bergh

The development of the breast is exquisitely sensitive to interactions between the epithelium and stroma. Experimental evidence indicates that a reduction in signalling between any of the stromal cell types (fibroblasts, macrophages, endothelial cells and adipocytes) results in reduced or absent breast development [1], although all interactions appear to be orchestrated by the epithelial cell oestrogen receptor alpha [2]. The epithelial-stromal interactions that occur in tumours are less well characterised but there is no doubt there is expansion of the stroma as well as of the epithelium during tumour development [3,4]. Recent data indicate that the prognosis after breast cancer diagnosis relates to stromal type, and experimental and clinical studies directed at modifying the stroma (for example, angiogenesis inhibitors) suggest that the stroma is a target for therapy that is worthy of further exploration

Studies of separately microdissected breast stroma and epithelium from normal lobules compared with ductal carcinoma in situ (DCIS) and invasive cancer indicate that extensive changes in gene expression in both the epithelial and stromal compartments occur during cancer development. These data strongly support the hypothesis that performing microdissections can be less optimal for gene expression profiling studies or to exclude cancers with a prominent stroma. Some array-based studies have had a requirement of more than $50 \%$ of cancer cells in the biopsies taken for array profiling; this may result in exclusion of biologically important cancers.

Compared with the intralobular stroma of the normal breast lobule, Ma and colleagues reported that 2,338 genes were upregulated and 1,234 genes were downregulated in the stroma of DCIS [5]. A further 76 genes were upregulated and 229 genes were downregulated in the stroma of invasive tumours, indicating that most of the changes had occurred in DCIS - suggesting that paracrine and endocrine influences are driving stroma

\footnotetext{
* Correspondence: Anthony.Howell@christie.nhs.uk Breakthrough Breast Cancer Research Unit, Paterson Institute for Cancer Research, University of Manchester, The Christie NHS Foundation Trust, University Hospital of South Manchester, Manchester M20 4BX, UK
}

formation rather than cell interactions, since the basement membrane is largely intact in DCIS. In a similar study examining stroma separated from the epithelium, Casey and colleagues demonstrated that the major changes of gene expression were upregulation of genes for the extracellular matrix and proteases in the stroma and downregulation of cytoskeletal proteins such as keratins, tubulins and adhesion molecules leading to increased cell motility in the tumour epithelium [6].

Invasive tumours have been likened to 'wounds that do not heal' [7]. In order to establish whether tumours induced gene expression similar to wounds, Chang and colleagues investigated whether they expressed the genes induced by serum in fibroblasts (the equivalent of wounding) $[8,9]$. The expression of 422 selected genes changed by serum in tumours was associated with a poor prognosis, whereas tumours with no change tended to have a good prognosis. In this study, although the genes were produced in serum-treated fibroblasts, they could have been expressed in epithelial cells of the tumours studied.

In order to assess the prognostic and predictive significance of genes strictly of stromal origin, Finak and colleagues isolated stroma from normal lobules and tumours by laser capture microdissection, and derived a 26-gene expression signature that was a poor prognostic indicator irrespective of breast tumour subtype and standard prognostic indicators and that also indicated resistance to standard treatments [10]. The stromal signature, however, has been described to be associated with a basal type of breast cancer in three independent datasets, including the Canadian study [11]. Other gene signatures derived from the whole tumour and searched for potential stromal genes were also able to detect a poor prognosis signature [12] and to detect a stromal signature that indicated failure to respond to neoadjuvant 5-fluorouracil, epirubicin, and cyclophosphamide chemotherapy [13].

More recently two groups have demonstrated downregulation of a protein (caveolin-1) that acts as a scaffold protein in cell surface pits or caveolae (important for 
signal transduction amongst other functions) in the stroma of invasive tumours and DCIS of poor prognosis [14-16]. Previous studies by the Lisanti group have shown that caveolin-1 is downregulated in fibroblasts during transformation and that recombinant expression of caveolin-1 in oncogenically transformed cells abrogates anchorage-independent growth, therefore biologically underpinning the observations in breast tumour stroma $[17,18]$.

The stroma, as shown by mammographic density, may also be changed in the normal breast during treatment with tamoxifen. We analysed stromal change over 12 to 18 months in the IBIS I tamoxifen prevention trial and demonstrated that women who had a tamoxifen-induced reduction of breast density were less likely to develop breast cancer [19]. This is consistent with the effect of tamoxifen in the rat breast, where it reduced proteolytic enzyme activity and extracellular matrix degradation [20].

These data outlines above indicate that certain types of tumour stoma may be related to the tendency of tumours to metastasise and related to resistance of the metastases to systemic therapy. There is evidence that factors secreted by the primary tumour such as osteopontin [21] and hypoxia-induced lysyl oxidase [22], and even systemically synthesised oestrogen $[23,24]$, can influence seeding of metastasis even before tumour cells migrate - leading to the concept of the pre-metastatic niche $[25,26]$.

Since the primary tumour is removed at surgery, the major target for therapy is the metastatic site (or sites harbouring dormant cells). Information concerning the effect on primary tumour or normal breast stroma can come from neoadjuvant and preventive studies, respectively. Little is known concerning the configuration of stroma at metastatic sites and whether or not it is similar to stroma in the primary tumour. Studies on tumour epithelium in matched primary tumours and metastases indicate that the phenotype of tumour epithelial cells can change, and thus the stroma might also change - indicating the important need for matched-pair studies on stroma as well as the epithelium [27]. Recent reviews have highlighted the potential of the tumour stroma as a target for therapy [28-30]. Antiangiogenic therapies and possibly bisphosphonates [31] are effective agents in current use targeting the stroma. There is great interest in targeting other cells, including tumour-associated fibroblasts [32,33], macrophages and other immune cells $[34,35]$, and the extracellular matrix, since there is strong evidence that extracellular matrix-associated cells, in contradistinction to isolated cells, may be resistant to therapy [36]. There is also interest in using altered or armed mesenchymal stem cells reinfused into the patient, which are likely to home to sites of injury such as tumours $[37,38]$. Alterations in the tumour stroma appear to be able to induce resistance to standard therapies as outlined above. Study of the mechanisms involved and ways to circumvent them are potentially important with respect to increased cure rates in women with breast cancer $[36,39]$.

In conclusion, the tumour stroma in breast has been neglected in many studies. Upcoming prevention, diagnostic and therapy strategies and studies should be carried out in an unbiased way, allowing analyses of the stromal compartment in addition to the classical investigations of the epithelial cancer component.

\section{Abbreviations}

DCIS: ductal carcinoma in situ.

\section{Acknowledgements}

This article has been published as part of Breast Cancer Research Volume 11 Suppl 3 2009: Controversies in Breast Cancer 2009. The full contents of the supplement are available online at http://breast-cancer-research.com/ content/11/S3.

\section{Competing interests}

The authors declare that they have no competing interests.

Published: 18 December 2009

\section{References}

1. Howell A, Sims AH, Ong KR, Harvie MN, Evans DG, Clarke RB: Mechanisms of disease: prediction and prevention of breast cancer-cellular and molecular interactions. Natl Clin Pract Oncol 2005, 2:635-646.

2. Mallepell S, Krust A, Chambon P, Brisken C: Paracrine signalling through the epithelial estrogen receptor alpha is required for proliferation and morphogenesis in the mammary gland. Proc Natl Acad Sci USA 2006, 103:2196-2201.

3. Wellings SR, Jensen HM, Marcum RG: An atlas of subgross pathology of the human breast with special reference to possible precancerous lesions. J Natl Cancer Inst 1975, 55:231-273.

4. Lee S, Mohsin SK, Mao S, Hilsenbeck SG, Medina D, Allred DC: Hormones, receptors and growth in hyperplastic enlarged lobular units: early potential precursors of breast cancer. Breast Cancer Res 2006, 8:R6.

5. Ma XJ, Dahiya S, Richardson E, Erlander M, Sgroi DC: Gene expression profiling of the tumor microenvironment during breast cancer progression. Breast Cancer Res 2009, 11:R7.

6. Casey T, Bond J, Tighe S, Hunter T, Lintault L, Patel O, Eneman J, Crocker A, White J, Tessitore J, Stanley M, Harlow S, Weaver D, Muss H, Plaut K: Molecular signatures suggest a major role for stromal cells in development of invasive breast cancer. Breast Cancer Res Treat 2009, 114:47-62.

7. Dvorak HF: Tumors: wounds that do not heal. Similarities between tumor stroma generation and wound healing. N Engl J Med 1986, 315:1650-1659.

8. Chang HY, Sneddon JB, Alizadeh AA, Sood R, West RB, Montgomery K, Chi JT, Rijn van de M, Botstein D, Brown PO: Gene expression signature of fibroblast serum response predicts human cancer progression: similarities between tumors and wounds. PLOS Biol 2004, 2:E7.

9. Chang HY, Nuyten DS, Sneddon JB, Hastie T, Tibshirani R, Sørlie T, Dai $H$, He YD, van't Veer L, Bartelink H, Rijn van de M, Brown PO, Vijver van de MJ: Robustness, scalability, and integration of a wound-response gene expression signature in predicting breast cancer survival. Proc Natl Acad Sci USA 2005, 102:3738-3743.

10. Finak $G$, Bertos $N$, Pepin F, Sadekova S, Souleimanova M, Zhao H, Chen $H$ Omeroglu G, Meterissian S, Omeroglu A, Hallett M, Park M: Stromal gene expression predicts clinical outcome in breast cancer. Nat Med 2008, 14:518-527.

11. Wennmalm K, Ostman A, Bergh J: Stromal signature identifies basal breast cancer. Nat Med 2009, 15:237-238. 
12. Bergamaschi A, Tagliabue E, Sørlie T, Naume B, Triulzi T, Orlandi R, Russness HG, Nesland JM, Tammi R, Auvininen P, Kosma VM, Menard S, Borresen-Dale AL: Extracelluar matrix signature identifies breast cancer subgroups with diferent clinical outcome. J Pathol 2008, 214:257-267.

13. Farmer $P$, Bonnefoi $H$, Anderle $P$, Cameron D, Wirapati $P$, Becette $V$, André S, Piccart M, Campone M, Brain E, Macgrogan G, Petit T, Jassem J, Bibeau F, Blot E, Bogaerts J, Aguet M, Bergh J, Iggo R, Delorenzi M: A stroma-related gene signature predicts resistance to neoadjuvant chemotherapy in breast cancer. Nat Med 2009, 15:68-74.

14. Witkiewicz AK, Dasgupta A, Sotgia F, Mercier I, Pestell RG, Sabel M, Kleer CG, Brody JR, Lisanti MP: An absence of stromal caveolin-1 expression predicts early tumor recurrence and poor clinical outcome in human breast cancers. Am J Pathol 2009, 174:2023-2034.

15. Witkiewicz AK, Dasgupta A, Nguyen KH, Liu C, Kovatich AJ, Schwartz GF, Pestell RG, Sotgia F, Rui H, Lisanti MP: Stromal caveolin-1 levels predict early DCIS progression to invasive breast cancer. Cancer Biol Ther 2009, 8:1071-1079

16. Sloan EK, Ciocca DR, Pouliot N, Natoli A, Restall C, Henderson MA Fanelli MA, Cuello-Carrión FD, Gago FE, Anderson RL: Stromal cell expression of caveolin-1 predicts outcome in breast cancer. Am J Pathol 2009, 174:2035-2043.

17. Koleske AJ, Baltimore D, Lisanti MP: Reduction of caveolin and caveolae in oncogenically transformed cells. Proc Nat Acad Sci USA 1995, 92:1381-1385.

18. Engelman JA, Wykoff CC, Yasuhara S, Song KK, Okamoto T, Lisanti MP: Recombinant expression of caveolin-1 in oncogeneity transformed cells abrogates anchorage-independent growth. J Biol Chem 1997, 272:16374-16381.

19. Cuzick J, Warwick J, Pinney L, Warren R, Cawthorn S, Howell A, Duffy S: Change in breast density as a biomarker of breast cancer risk reduction results from IBIS I [abstract]. San Antonio Breast Cancer Symposium; 10-14 December 2008 [http://www.abstracts2view.com/sabcs/]

20. Hattar R, Maller O, McDaniel S, Hansen KC, Hedman K, Lyons TR, Lucia S, Wilson RS Jr, Schedin P: Tamoxifen induces pleiotrophic changes in mammary stroma resulting in extra-cellular matrix that suppresses transformed phenotypes. Breast Cancer Res 2009, 11:R5.

21. McAllister SS, Gifford AM, Greiner AL, Kelleher SP, Saelzler MP, Ince TA, Reinhardt F, Harris LN, Hylander BL, Repasky EA, Weinberg RA: Systemic endocrine instigation of indolent tumor growth requires osteopontin Cell 2008, 133:994-1005.

22. Erler JT, Bennewith KL, Cox TR, Lang G, Bird D, Koong A, Le Q-T, Giaccia AJ: Hypoxia-induced lysyl oxidase is a critical mediator of bone marrow cell recruitment to form the premetastatic niche. Cancer Cell 2009, 15:35-44.

23. Banka CL, Lung CV, Nguyen MTN, Pakchoian AJ, Mueller BM, Eliceiri BP: Estrogen induces lung metastasis through a host compartment-specific response. Cancer Res 2006, 66:3667-3672.

24. Gupta PB, Proia D, Cingoz O, Weremowicz J, Naber SP, Weinberg RA, Kuperwasser C: Systemic stromal effects of estrogen promote the growth of estrogen receptor-negative cancers. Cancer Res 2007, 67:2062-2071.

25. Joyce JA, Pollard JW: Microenvironment regulation of metastasis. Nat ReV 2009, 9:239-252

26. Psaila B, Lyden D: The metastatic niche: adapting the foreign soil. Nat Rev 2009, 9:285-293.

27. Broom RJ, Tang PA, Simmons C, Bordeleau L, Mulligan AM, O'Malley FP, Miller N, Andrulis IL, Brenner DM, Clemons MJ: Changes in estrogen receptor, progesterone receptor and Her-2/neu status with time: discordance rates between primary and metastatic breast cancer. Anticancer Res 2009, 29:1557-1562.

28. Gadea BB, Joyce JA: Tumour-host interactions: implications for developing anti-cancer therapies. Expert Rev Mol Med 2006, 8:1-32

29. Ronnov-Jessen L, Bissell MJ: Breast cancer by proxy: can the microenvironment be both the cause and consequence? Trends Mol Med 2009, 15:5-13.

30. Ostman A, Augsten M: Cancer-associated fibroblasts and tumour growthbystanders turning into key players. Curr Opin Genet Dev 2009, 19:67-73.

31. Morton AR, Cantrill JA, Pillai GV, McMahon A, Anderson DC, Howell A: Sclerosis of lytic bone metastases after disodium aminohydroxypropylidene bisphosphonate (APD) in patients with breast carcinoma. Br Med J 1988, 297:772-773.
32. Lebeau AM, Brennen WN, Aggarwal S, Denmeade SR: Targeting the cancer stroma with a fibroblast activation protein-activated promelittin protoxin. Mol Cancer Ther 2009.

33. Iwasaki Y, Akari H, Murakami T, Kumakura S, Dewan Z, Yanaka M, Yamamoto N: Efficient inhibition of SDF-1a [GREEK]-mediated chemotaxis and HIV-1 infection by novel CXCR4 antagonists. Cancer SCi 100:778-781.

34. Luo Y, Zhou H, Kreuger J, Kaplan C, Lee SH, Dolman C, Markowitz D, Wu W, Liu C, Reidfeld RA, Xiang R: Targetting tumour-associated macrophages as a novel strategy against breast cancer. J Clin Invest 116:2132-2141.

35. Garber K: First results for agents targeting cancer-related inflammation. J Natl Cancer Inst 2009, 101:1110-1112.

36. Meads MB, Gatenby RA, Dalton WS: Environment-mediated drug resistance: a major contributor to minimal residual disease. Nat Rev 2009, 9:665-675

37. Fritz $V$, Jorgensen $C$ : Menenchymal stem cells: an emerging tool for cancer targeting and therapy. Curr Stem Cell Res Ther 2008, 3:32-42.

38. Kucerova L, Altanerova V, Matuskova M, Tyciakova S, Altaner C: Adiposederived human mesenchymal stem cell mediated prodrug gene therapy. Cancer Res 2007, 67:6304-6313.

39. Shekhar MP, Santner S, Carolin KA, Tait L: Direct involvement of breast tumor fibroblasts in the modulation of tamoxifen sensitivity. Am J Pathol 2007, 170:1546-1560

doi: $10.1186 / \mathrm{bcr} 2435$

Cite this article as: Howell et al:: Breast tumour stroma is a prognostic indicator and target for therapy. Breast Cancer Research 2009 11:S16.

\section{Submit your next manuscript to BioMed Central and take full advantage of:}

- Convenient online submission

- Thorough peer review

- No space constraints or color figure charges

- Immediate publication on acceptance

- Inclusion in PubMed, CAS, Scopus and Google Scholar

- Research which is freely available for redistribution

Submit your manuscript at www biomedcentral com/submit
C) Biomed Central 